\title{
Kemampuan Pemahaman Konsep pada Materi Sistem Persamaan Linear Dua Variabel Berdasarkan Teori APOS Bagi Siswa SMP
}

\author{
Ferdi F Kadafuk $^{1 \bowtie}$, Kristoforus Djawa Djong², Irmina Veronika Uskono ${ }^{3}$ \\ ${ }^{1,2,3}$ Program Studi Pendidikan Matematika Universitas Katolik Widya Mandira
}

\begin{tabular}{|c|c|}
\hline Info Artikel & Abstract \\
\hline $\begin{array}{l}\text { SejarahArtikel: } \\
\text { Diterima } 24 \text { Juni } 2020 \\
\text { Direvisi } 19 \text { Nov } 2020 \\
\text { Disetujui } 20 \text { Nov } 2020\end{array}$ & $\begin{array}{l}\text { This research is a qualitative research that aims to analyze the understanding of mathematical } \\
\text { concepts of students of one of the yunior high school in Kupang city in problem solving on the material } \\
\text { system of two-variable linear equations. The subjects in this study were three students of class VIII } \\
\text { who had high ability, medium ability, and low ability. The selection of subjects were based UTS results } \\
\text { and discussions with mathematics teacher. Data collected in the form of data on the results of problem }\end{array}$ \\
\hline $\begin{array}{l}\text { Keywords: Consept } \\
\text { understanding ability, } \\
\text { APOS theory, SPLDV }\end{array}$ & $\begin{array}{l}\text { solving tasks and the results of interviews based on indicators of understanding of the concept. Data } \\
\text { analysis includes data reduction, data presentation, and drawing conclusions. Checking the validity } \\
\text { of the data using time triangulation. After the data is presented and analyzed, it can be concluded that } \\
\text { (1) Students with high ability results are able to solve the given problems and meet the indicators of }\end{array}$ \\
\hline $\begin{array}{l}\text { Paper type: } \\
\text { Research paper }\end{array}$ & $\begin{array}{l}\text { the ability to understand concepts based on APOS theory. (2) Students with medium ability results } \\
\text { are fulfilling the ability to understand concepts based on APOS theory. (3) While students with low } \\
\text { ability results do not meet the indicators of the ability to understand concepts based on APOS theory. }\end{array}$ \\
\hline
\end{tabular}

\begin{abstract}
Abstrak
Penelitian ini merupakan penelitian kualitatif yang bertujuan untuk menganalisis pemahaman konsep matematika siswa salah satu SMP di Kota Kupang dalam pemahaman konsep pada materi sistem persamaan linear dua variabel. Subyek dalam penelitian ini adalah tiga siswa kelas VIII yang memiliki kemampuan tinggi, sedang, dan rendah. Pemilihan subyek dilakukan berdasarkan hasil ujian tengah semester (UTS) siswa dan juga hasil diskusi dengan guru mata pelajaran matematika. Data yang dikumpulkan berupa data hasil tugas pemahaman konsep dan hasil wawancara berdasarkan indikator pemahaman konsep. Analisis data mencakup reduksi data, penyajian data, dan penarikan kesimpulan. Pengecekkan keabsahaan data menggunakan triangulasi waktu. Setelah data dipaparkan dan dianalisis, maka dapat disimpulkan bahwa (1) Siswa dengan kemampuan tinggi mampu menyelesaikan soal yang diberikan dan memenuhi indikator kemampuan pemahaman konsep berdasarkan teori APOS. (2) Siswa dengan kemampuan sedang memenuhi indikator kemampuan pemahaman konsep berdasarkan teori APOS. (3) Sedangkan siswa dengan kemampuan rendah tidak memenuhi indikator kemampuan pemahaman konsep berdasarkan teori APOS.
\end{abstract}

(C) 2020 Universitas Muria Kudus

\begin{tabular}{l}
\hline Alamatkorespondensi: \\
Program Studi Pendidikan Matematika \\
Fakultas Keguruan dan Ilmu Pendidikan Universitas Muria Kudus \\
Kampus UMK Gondangmanis, Bae Kudus Gd. L. 1t I PO. BOX 53 Kudus \\
Tlp (0291) 438229 ex.147 Fax. (0291) 437198 \\
E-mail:fkadafuk@gmail.com, veniuskono@gmail.com
\end{tabular}




\section{PENDAHULUAN}

Matematika memiliki peran penting dalam berbagai aspek kehidupan, meskipun dalam perhitungan sederhana, seperti menghitung untung rugi, menghitung luas bangunan, menghitung besar pendapatan. Menurut (Turmudi, 2008) matematika merupakan pelajaran penting yang tak terpisahkan dari pendidikan secara umum karena gagasan-gagasan seperti bilangan, ruang, pengukuran, dan susunan, telah beratus-ratus bahkan ribuan tahun digunakan dalam kehidupan sehari-hari oleh sebagian besar manusia, sehingga gagasangagasan itu juga digunakan dalam sains, ekonomi, dan desain serta dalam teknologi informasi dan komunikasi dewasa ini tidak terlepas dari perkembangan matematika. Karena itu matematika diajarkan dari tingkat sekolah dasar sampai tingkat perguruan tinggi.

(Daswa, 2013) menyatakan bahwa pembelajaran matematika memiliki fungsi sebagai sarana untuk mengembangkan kemampuan berpikir kritis, logis, kreatif, komunikatif, kerjasama, serta pemahaman konsep yang diperlukan siswa dalam kehidupan modern ini. Keterampilan berpikir kreatif ini berkaitan dengan kemampuan mengidentifikasi, menganalisis, dan memecahkan masalah secara kreatif serta berfikir logis sehingga menghasilkan pertimbangan dan keputusan yang tepat. Proses berpikir kreatif sangat tergantung pada cara siswa belajar dan merespon masalah matematika.

Menurut (Depdiknas, 2003) pentingnya pemahaman konsep matematika berada dalam tujuan pertama pembelajaran matematika yaitu memahami konsep matematika, menjelaskan keterkaitan antar konsep dan mengaplikasikan konsep atau algoritma secara luwes, akurat, efisien dan tepat dalam pemahaman konsep. Oleh karena itu pemahaman konsep matematika dapat membantu siswa dalam belajar matematika. Hasil dari proses pemahaman konsep dapat membina ingatan siswa dalam jangka panjang tentang sesuatu konsep melalui keterlibatan aktif dalam mengaitkan pengetahuan yang diterima dengan pengetahuan yang dimiliki untuk membina pengetahuan baru (Sholikhakh, Rismono, \& Waluya, 2012). Pemahaman siswa terhadap suatu konsep matematika sangat penting, karena dengan penguasaan konsep akan memudahkan siswa mempelajari matematika. Jadi dapat disimpulkan bahwa pemahaman konsep adalah suatu proses untuk menangkap makna gambaran dari beberapa objek atau kejadian yang sesungguhnya.

Dalam proses pembelajaran, siswa diharapkan tidak hanya mendengar, mencatat, menghafal materi maupun rumus-rumus yang diberikan guru, melainkan siswa dituntut berperan aktif dalam kegiatan pembelajaran sehingga mampu memahami konsep dan bisa memecahkan berbagai persoalan dalam matematika. Menurut (Sumliyah \& Rhosliana, 2018) dalam memahami konsep matematika diperlukan kemampuan generalisasi serta abstraksi yang cukup tinggi. Sedangkan saat ini penguasaan siswa terhadap materi konsep matematika masih lemah bahkan dipahami dengan keliru.

Berdasarkan hasil pengamatan pada praktek pengalaman lapangan yang dilakukan di salah satu SMP Swasta di Kota Kupang, ditemukan kelemahan yang nampak dari kemampun siswa pada pelajaran matematika. Salah satu materi dalam matematika yang sulit dipahami oleh siswa yaitu sistem persamaan linear dua variabel (SPLDV) karena banyaknya konsep dan aplikasinya yang digunakan dalam kehidupan sehari-hari. Siswa memahami maksud dari soal, namun siswa belum menguasai operasi hitung aljabar pada materi SPLDV.

Untuk mengetahui kesulitan dan kendala siswa dalam memahami materi SPLDV, maka diperlukan sebuah teori untuk memeriksa kemampuan pemahaman siswa terhadap konsep. (Mulyono, 2011) mengemukakan sebuah teori untuk mempelajari bagaimana seseorang belajar konsep matematika, yaitu teori APOS (Action, Proces, Object, dan Schema). Teori APOS hadir sebagai upaya untuk memahami mekanisme abstraksi reflektif yang diperkenalkan oleh Piaget untuk menggambarkan perkembangan berpikir logis anak, dan memperluas ide ini untuk konsepkonsep matematika lanjut. Lebih lanjut, (Lestari, 2014) menyatakan bahwa tujuan yang ingin dicapai dari teori APOS adalah terbentuknya kontruksi mental pembelajar. Kontruksi mental ini adalah terbentuknya aksi, yang direnungkan (interiorized) menjadi proses, selanjutnya dirangkum (encapsulated) menjadi objek, kemudian objek dapat diurai kembali (deencapsulated) menjadi proses. Aksi, proses, dan objek dapat diorganisasikan menjadi suatu skema, yang selanjutnya disingkat menjadi APOS. Berdasarkan uraian di atas, maka tujuan yang ingin dicapai dalam penelitian ini yaitu untuk mengetahui kemampuan pemahaman konsep materi sistem persamaan linear dua variabel berdasarkan teori APOS pada siswa SMP.

\section{METODE PENELITIAN}

Jenis penelitian yang digunakan adalah deskriptif kualitatif.Penelitian ini dilaksanakan di Kelas VIII salah satu SMP swasta di Kota 
Kupang. Subyek dalam penelitian ini yaitu 3 orang siswa yang memiliki hasil Uijian Tengah Semester (UTS) tinggi, sedang, dan rendah. Selain itu pemilihan subyek juga berdasarkan hasil diskusi antara peneliti dan guru mata pelajaran matematika. Pada Tabel 1 dapat dilihat kriteria dalam pemilihan subyek.

Tabel 1. Kriteria Pemilihan Subyek

\begin{tabular}{ccc}
\hline No & Kriteria & Rentang Nilai \\
\hline 1 & Rendah & $60-70$ \\
2 & Sedang & $71-80$ \\
3 & Tinggi & $81-100$ \\
\hline
\end{tabular}

Instrumen penelitian yang digunakan dalam penelitian ini antara lain: instrumen utamayaitu peneliti sendiri dan instrumen pendukung. Intrumen pendukung yang digunakan dalam penelitian ini adalah tugas pemahaman konsep (TPK) berupa soal matematika dalam bentuk soal uraian, yang dikerjakan oleh ketiga subyek di kelas VIII dan pedoman wawancara. Pedoman wawancara dalam penelitian ini berupa, pertanyaan-pertanyaan tentang informasi yang berkaitan dengan indikator pemahaman konsep matematikasiswa pada materi sistem persamaan linear dua variabel. Jenis wawancara yang digunakan adalah wawancara semiterstruktur.

Teknik pengumpulan data yang digunakan dalam penelitian ini meliputi: 1) Pemberian tesberupa dua buah butir soal yang telah dikonsultasikan dengan dosen pembimbing dan layak digunakan pada materi sistem persamaan linear dua variabel yang akan dikerjakan ketiga subyek. 2) Wawancara, wawancara (interview) dilakukan dengan menanyakan langsung pada subyek yang diteliti. Wawancara ini juga dilakukan untuk menggali informasi langsung dari subyek. Metode wawancara ini dilaksanakan berdasarkan daftar pertanyaan dalam bentuk pedoman wawancara. Pengecekan keabsahan data dalam penelitian ini menggunakan teknik triangulasi, yaitu triangulasi waktu. Teknik analisis data yang digunakan dalam penelitian ini yaitu, menggunakan 1) Reduksi data, 2) Tahap klasifikasi, 3) Penarikan kesimpulan.

\section{HASIL DAN PEMBAHASAN}

Pemilihan subyek dilakukan berdasarkan kemampuan siswa dan juga berdasarkan hasil diskusi antara peneliti dan guru mata pelajaran matematika.

Tabel 2. Subyek Penelitian

\begin{tabular}{cccc}
\hline No & $\begin{array}{c}\text { Nama } \\
\text { Subyek }\end{array}$ & Skor & Kelompok \\
\hline 1 & DS & 85 & Tinggi \\
2 & YB & 74 & Sedang \\
3 & VD & 40 & Rendah \\
\hline
\end{tabular}

Tabel 3 merupakan instrumen tugas pemahaman konsep yang digunakan

Tabel 3. Tugas Pemahaman Konsep

\begin{tabular}{ll}
\hline \multicolumn{1}{c}{ TPK I } & \multicolumn{1}{c}{ TPK II } \\
\hline Harga $7 \mathrm{~kg}$ terigu dan 2 & Harga 11 kg beras dan 5 \\
kg gula sama dengan Rp. & buah apel sama dengan \\
70.000,-. Jika harga $3 \mathrm{~kg}$ & $\mathrm{Rp} .123 .000,-$. Jika harga \\
terigu dan $2 \mathrm{~kg}$ gula sama & $6 \mathrm{~kg}$ beras dan 4 buah \\
dengan Rp. 38.000,-, & apel sama dengan Rp. \\
berapa harga 2 kg terigu & $76.000,-$, berapa harga 5 \\
dan 1 kg gula tersebut? & $\mathrm{kg} \mathrm{beras} \mathrm{dan} \mathrm{2} \mathrm{apel}$ \\
& tersebut? \\
\hline
\end{tabular}

A. Paparan Data Subyek Berkemampuan Tinggi dalam tahapan Indikator Teori APOS

1. Deskripsi Hasil TPK I

Berikut hasil wawancara subyek DS pada TPK I:

$P \quad: \quad$ Coba adik sebut hal-hal yang diketahui dari 107 soal tersebut!

DS : Harga $7 \mathrm{~kg}$ terigu dan $2 \mathrm{~kg}$ gula sama dengan

$107 \quad$ Rp.70.000,-, dan harga $3 \mathrm{~kg}$ terigu dan $2 \mathrm{~kg}$ gula sama dengan Rp. 38.000,-. Itu yang diketahui.

$P \quad: \quad$ Oke baik, kalau begitu apa yang ditanyakan?

108

$D S$

108

$P$

109

Yang ditanyakan harga $2 \mathrm{~kg}$ terigu dan $1 \mathrm{~kg}$ gula.

Baik adik, kalau begitu coba adik jelaskan yang adik tulis ini

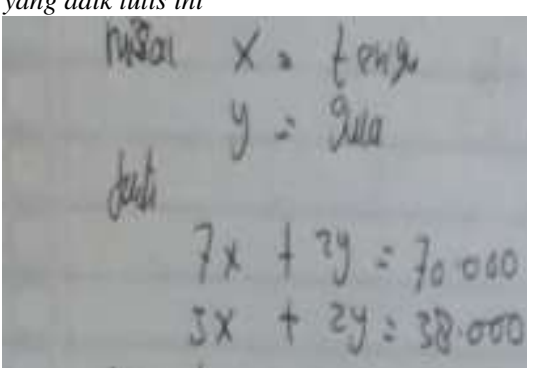

DS : Begini pak, pertama saya buat itu saya

109 misalkan terigu adalah $x$ dan gula adalah $y$ setelah itu saya ubah ke bentuk persamaan

$P \quad:$ Oke adik, langkah apa yang adik buat

110 selanjutnya?

DS Saya gunakan metode eliminasi pak

110

$P$

111

Kalau begitu, coba adik jelaskan ini

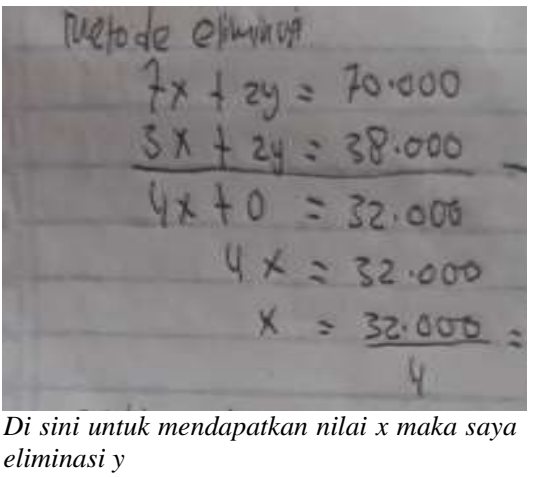


$P \quad$ : Baik adik, terus apa lagi langkah selanjutnya?

113

DS : Selanjutnya saya gunakan metode substitusi

113 pak

$P \quad$ : Kalau begitu, coba adik jelaskan ini

114

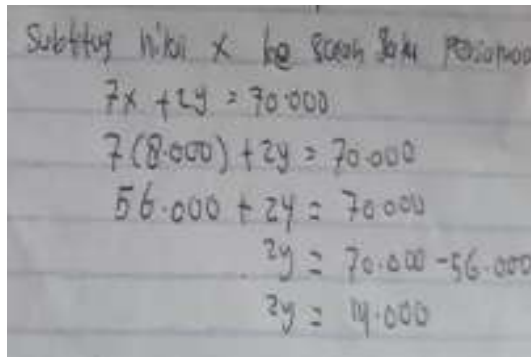

DS : Begini pak, setelah saya dapat

$114 \quad$ nilai $x$ maka saya substitusikan nilai $x$ ke salah satu persamaan untuk mendapatkan nilai y

$P \quad$ : Oke adik, coba jelaskan ini

116

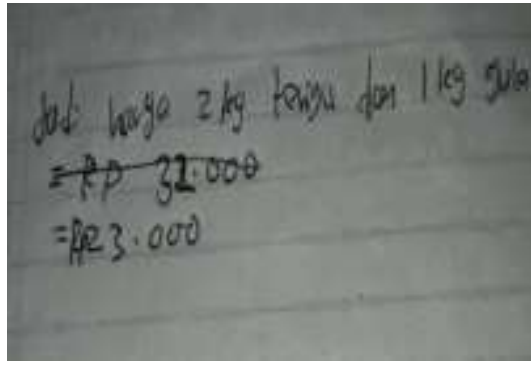

$D S$

Di sini saya buat kesimpulan

116 harga $1 \mathrm{~kg}$ terigu sama dengan nilai x yaitu Rp. 8.000,- dan $1 \mathrm{~kg}$ gula sama dengan nilai y yaitu Rp. 7.000,- maka harga $2 \mathrm{~kg}$ terigu dan $1 \mathrm{~kg}$ gula sama dengan Rp. 23.000,-

\section{Deskripsi Hasil TPK II}

Berikut hasil wawancara subyek DS pada TPK II:
$P \quad$ : Coba adik sebutkan hal-hal
207 yang diketahui dari soal tersebut
DS : Harga $11 \mathrm{~kg}$ beras dan 5 buah apel sama dengan $R p .123 .000$, dan harga $6 \mathrm{~kg}$ beras dan 4 buah apel sama dengan $R p$. 76.000. Itu yang diketahui pak.
$P \quad$ : Oke baik, kalau begitu apa yang
208 ditanyakan?
DS : Yang ditanyakan harga $5 \mathrm{~kg}$ beras
208 dan 2 buah apel pak
$P \quad$ : Baik adik, kalau begitu coba adik

209 jelaskan yang adik tulis ini

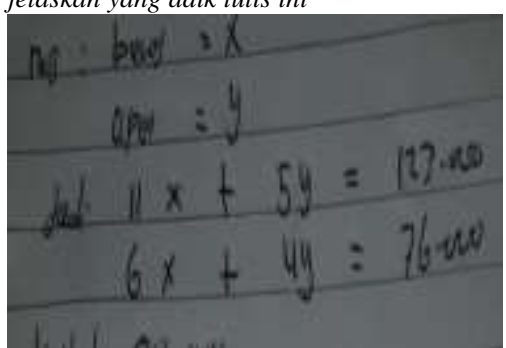

DS : Begini pak, pertama saya buat

209 itu saya misalkan beras adalah $x$ dan apel adalah $y$, setelah itu saya ubah ke bentuk persamaan

$P \quad: \quad$ Oke adik, terus langkah apa

$210 \quad$ yang adik buat selanjutnya?

DS : Saya gunakan metode eliminasi

210 pak

$P \quad$ : Kalau begitu, coba adik

211 jelaskan ini

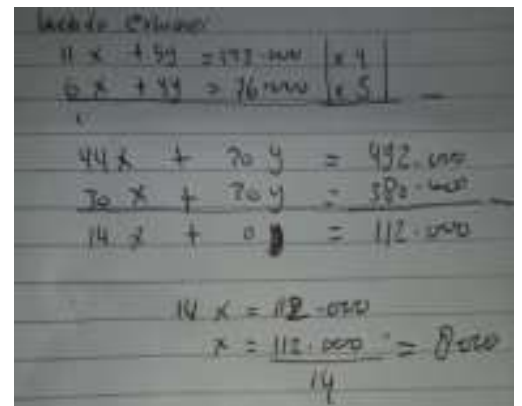

$D S$

211

$P$

213

DS

213

$P$

214

DS : Begini pak, setelah saya dapat nilai x maka 214 saya substitusikan nilai $x$ ke salah satu persamaan untuk mendapatkan nilai y

$P \quad$ : Oke adik, coba adik jelaskan ini

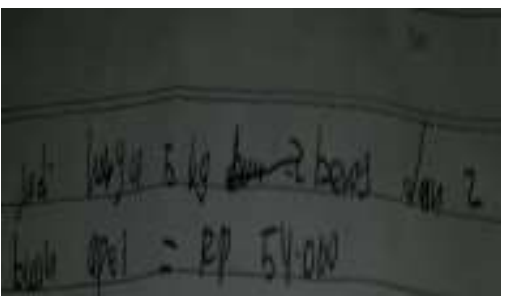

$D S \quad$ : $D i$ sini saya buat kesimpulan harga $1 \mathrm{~kg}$ 216 beras sama dengan nilai x yaitu Rp. 8000,dan 1 buah apel sama dengan nilai y yaitu Rp.7.000,-, maka harga $5 \mathrm{~kg}$ beras dan 2 buah apel dama dengan Rp.54.000,

3. Validasi Data Subjek Berkemampuan Tinggi

Untuk mengetahui validitas data kemampuan pemahaman konsep subjek DS berdasarkan teori APOS maka dilakukan triangulasi waktu untuk memperoleh kesamaan 
data wawancara. Triangulasi tersebut dalam dilihat pada Tabel 4.

Tabel 4. Validasi data Subyek DS

\begin{tabular}{|c|c|}
\hline & \\
\hline $\begin{array}{l}\text { va mampu } \\
\text { lentukan apa yang } \\
\text { etahui dari soal yang } \\
\text { erikan. (DS 107) }\end{array}$ & $\begin{array}{l}\text { a mampu } \\
\text { entukan apa yang } \\
\text { ahui dari soal yang } \\
\text { ikan. (DS 207) }\end{array}$ \\
\hline \begin{tabular}{lrr} 
iswa & \multicolumn{2}{r}{ mampu } \\
lenentukan & apa & yang \\
itanyakan & dari & soal \\
rrsebut. (DS 108) &
\end{tabular} & \begin{tabular}{|lrr} 
Siswa & \multicolumn{2}{c}{ mampu } \\
menentukan apa & yang \\
ditanyakan dari & soal \\
tersebut. (DS 208) & \\
\end{tabular} \\
\hline $\begin{array}{l}\text { mampu merubah } \\
\text { dalam bentuk } \\
\text { matematika. (DS }\end{array}$ & $\begin{array}{lcc}\text { Siswa } & \text { mampu me } \\
\text { soal } & \text { dalam } & \text { b }\end{array}$ \\
\hline $\begin{array}{l}\text { mampu } \\
\text { ntukan langkah- } \\
\text { ah penyelesaian } \\
\text { (DS 110, DS 113) }\end{array}$ & $\begin{array}{l}\text { Siswa mampu } \\
\text { menentukan langkah- } \\
\text { langkah penyelesaian } \\
\text { soal. (DS 210, DS 213) }\end{array}$ \\
\hline $\begin{array}{lr} & \text { mampu } \\
\text { elesaikan } & \text { soal } \\
\text { an langkah-langkah } \\
\text { elesaian }\end{array}$ & $\begin{array}{lr}\text { a } & \text { mampu } \\
\text { jelesaikan } & \text { soal } \\
\text { an langkah-langkah } \\
\text { elesaian }\end{array}$ \\
\hline & \\
\hline
\end{tabular}

Dari paparan wawancara di atas, terungkap bahwa subjek berkemampuan tinggi untuk indikator pemahaman konsep berdasarkan teori APOS (Mulyono, 2011) pada TPK I yaitu:

1. Pada tahap tindakan

Subjek DS mampu menuliskan dan menjelaskan secara verbal apa yang diketahui dan ditanyakan dalam soal serta mampu menentukan dan menjelaskan secara verbal rencana untu menyelesaikan soal cerita yang berkaiatan dengan SPLDV

2. Pada tahap proses

Subjek DS mampu mengubah soal ke dalam bentuk matematika tanpa bantuan tulisan atau gambar serta mampu melakukan perhitungan langsung.

3. Pada tahap objek

Subjek DS dapat menyelesaikan soal dan langkah yang digunakan beserta alasan sesuai dengan metode penyelesaian

4. Pada tahap skema

Subjek DS mampu menggunakan konsep serta prosedur dalam menyelesaikan soal cerita yang berkaitan dengan sistem persamaan linear dua vaiabel serta mampu menggunakan dan memilih prosedur tertentu untuk menyelesaikan soal sistem persamaan linear dua variabel dengan tepat dan sesuai prosedur.

B. Paparan Data Subyek Berkemampuan Sedang Dalam tahapan Indikator Teori APOS

1. Deskripsi Hasil TPK I

Berikut hasil wawancara subyek YB pada TPK I:

$P \quad: \quad$ Coba adik sebutkan hal-hal yang diketahui dari soal 107 tersebut

$Y B \quad$ : Harga $7 \mathrm{~kg}$ terigu dan $2 \mathrm{~kg}$ gula sama dengan

$107 \quad$ Rp.70.000,- dan harga $3 \mathrm{~kg}$ terigu dan $2 \mathrm{~kg}$ gula sama dengan Rp.38.000,-. Itu yang diketahui pak

$P \quad: \quad$ Oke baik, kalau begitu apa yang ditanyakan?

108

$Y B$

108

$P$

109

Yang ditanyakan harga $2 \mathrm{~kg}$ terigu dan $1 \mathrm{~kg}$ gula, pak

Baik adik, kalau begitu coba adik jelaskan yang adik tulis ini

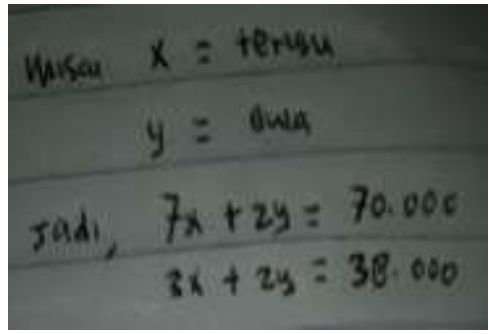

YB : Begini pak, pertama saya buat itu saya misalkan 109 terigu adalah $x$ dan gula adalah y baru setelah itu saya ubah ke bentuk persamaan

$P \quad: \quad$ Oke adik, terus langkah apa yang adik buat

110 selanjutnya?

$Y B \quad$ : Saya gunakan metode eliminasi pak

110

$P$
111

Kalau begitu, coba adik jelaskan ini

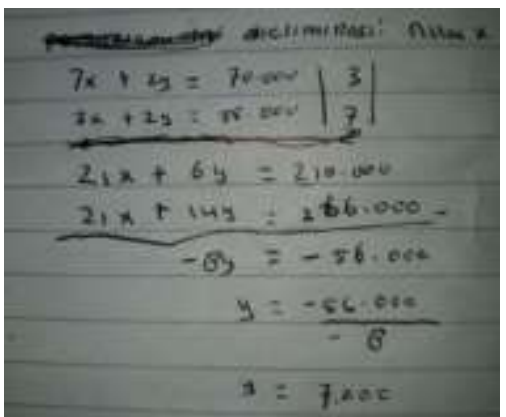

$Y B \quad$ : Disini untuk mendapatkan nilai y maka saya eliminas 111 nilai $x$

$P \quad: \quad$ Oke adik, terus langkah selanjutnya, apa yang adik

114 buat?

$Y B \quad$ : Selanjutnya saya substitusi, pak

114

$P$ 115
Kalau begitu, coba adik jelaskan ini 
Ferdi F Kadafuk, Kristoforus Djawa Djong, Irmina Veronika Uskono Anargya: Jurnal Pendidikan Matematika, Vol.3 No.2, Oktober 2020
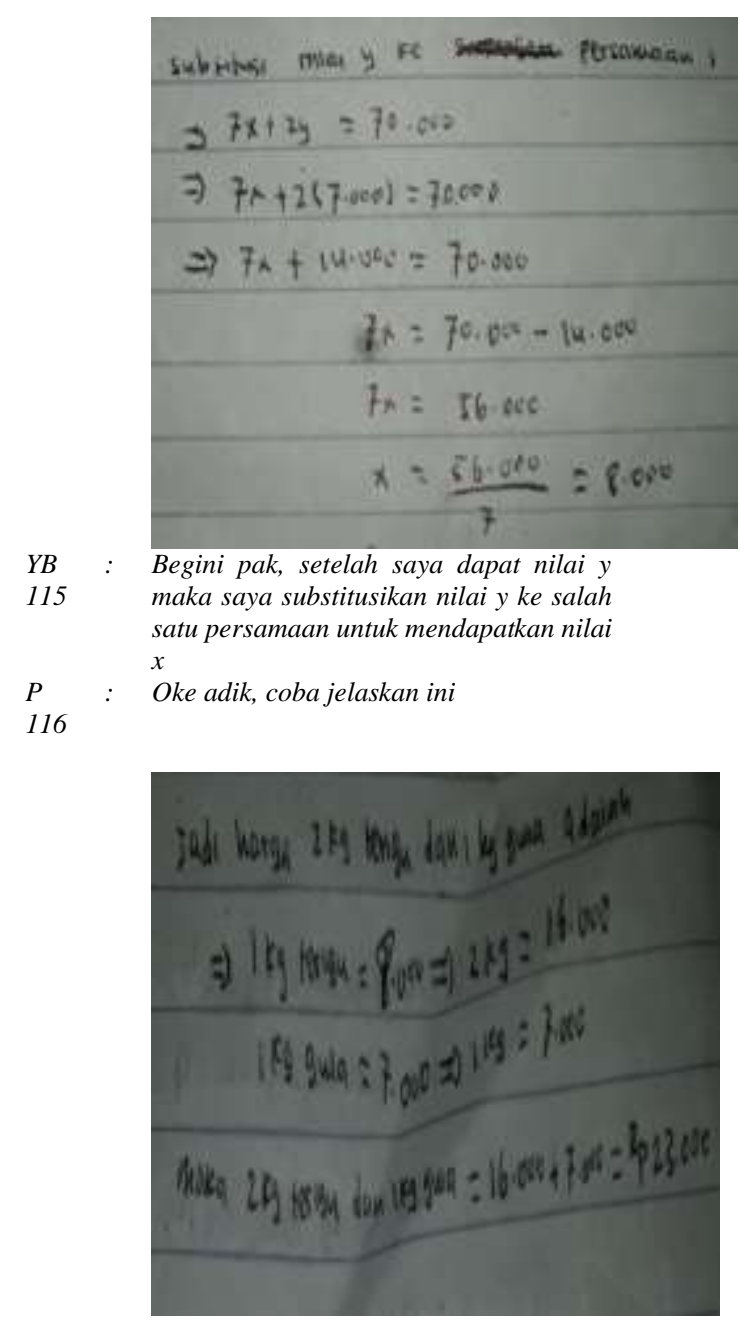

$Y B \quad$ : Disini saya buat kesimpulannya harga $1 \mathrm{~kg}$

116 terigu sma dengan nilai $x$ yaitu Rp. 8.000,dan $1 \mathrm{~kg}$ gula sama dengan nilai y yaitu Rp.7.000,- maka harga $2 \mathrm{~kg}$ terigu dan $1 \mathrm{~kg}$ gula sama dengan Rp. 23.000,-

\section{Deskripsi Hasil TPK II}

Berikut hasil wawancara subyek YB pada TPK II:

P207 : Coba adik sebut hal-hal yang diketahui dari soal tersebut

$Y B \quad$ : Harga $11 \mathrm{~kg}$ beras dan 5 buah apel sama

207 dengan RP.123.000 dan harga $6 \mathrm{~kg}$ beras dan 4 buah apel sama dengan Rp.76.000. Itu yang di ketahui pak

P208 : Oke baik, kalo begitu apa yang di tanyakan?

YB : Yang di tanyakan harga $5 \mathrm{~kg}$ beras dan 2 $208 \quad$ buah apel pak

P209 : Baik adik, klo begitu coba adik jelaskan yang adik tulis ini

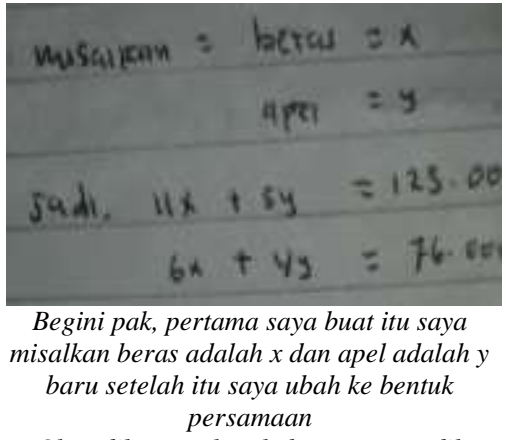

P210 : $\quad$ Oke adik, terus langkah apa yang adik buat selanjutnya?

YB : $\quad$ Saya gunakan metode eliminasi pak

210

P211 : $\quad$ Kalo begitu coba adik jelaskan ini

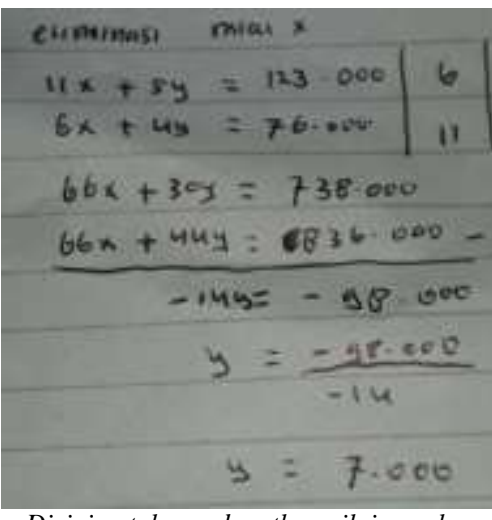

$$
\begin{aligned}
& Y B \quad \text { : } \quad \text { Disini untuk mendapatkan nilai y maka } \\
& 211 \quad \text { saya eliminasi nilai } x
\end{aligned}
$$

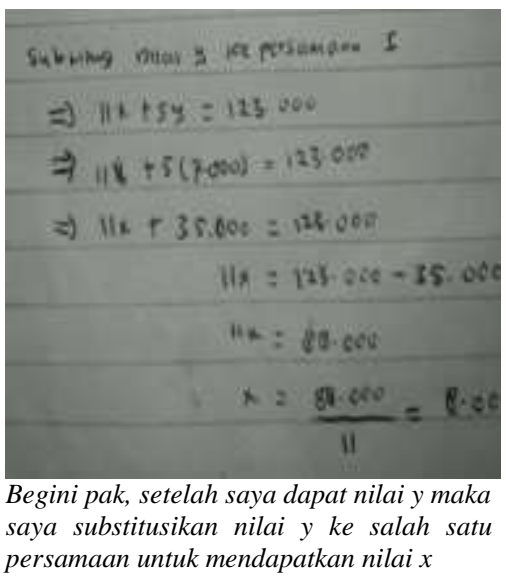




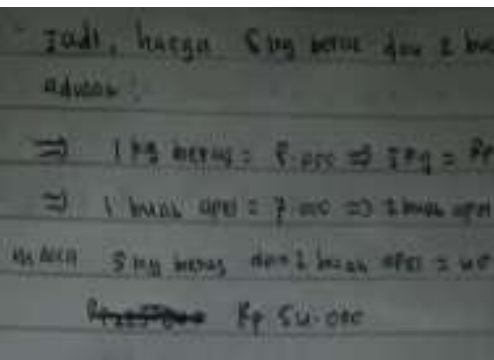

YB21 Disini saya buat kesimpulannya harga $1 \mathrm{~kg}$

$6 \quad$ beras sama dengan nilai $x$ yaitu $\mathrm{Rp} 8.000$ dan 1 buah apel sama dengan nilai y yaitu Rp 7.000 maka harga 5 kg beras dan 2 buah apel sama dengan Rp 54.000

P217 Oke baik adik terima kasih

YB21 Sama-sama pak.

1. Pada tahap tindakan

Subjek YB mampu menuliskan dan menjelaskan secara verbal apa yang diketahui dan ditanyakan dalam soal serta mampu menentukan dan menjelaskan secara verbal rencana untukmenyelesaikan soal cerita yang berkaiatan dengan SPLDV

2. Pada tahap proses

Subjek YB mampu mengubah ke dalam bentuk matematika tanpa bantuan tulisan atau gambar serta mampu melakukan perhitungan langsung.

3. Pada tahap objek

Subjek YB dapat menyelesaikan soal dan langkah yang digunakan beserta alasan sesuai dengan metode penyelesaian.

4. Pada tahap skema

Subjek YB mampu menggunakan konsep serta prosedur dalam menyelesaikan soal cerita yang berkaitan dengan sistem persamaan linear dua vaiabel serta mampu menggunakan dan memilih prosedur tertentu untuk menyelesaikan soal sistem persamaan linear dua variabel dengan tepat dan sesuai prosedur.

C. Paparan Data Subyek Berkemampuan RendahDalam tahapan Indikator Teori APOS

1. Deskripsi Hasil TPK I TPK I:

Berikut hasil wawancara subyek VD pada

menentukan apa yang menentukan apa yang diketahui dari soal. (YB diketahui dari soal. (YB 107) 207)

Siswa mampu Siswa mampu menentukan apa yang menentukan apa yang ditanyakan. (YB 108) ditanyakan. (YB 208)

Siswa mampu merubah Siswa mampu merubah soal kedalam bentuk soal kedalam bentuk kalimat matematika. kalimat matematika. (YB (YB 109) 209)

Siswa mampu Siswa mampu

menentukan langkah menentukan langkah penyelesaian. (YB 110, penyelesaian. (YB 210, YB 114) YB 213)

Siswa mampu Siswa mampu

menyelesaikan soal menyelesaikan soal dengan langkah-langkah dengan langkah-langkah penyelesaian yang penyelesaian yang ditentukan. (YB 111, YB ditentukan. (YB 211, YB 115) 214)

Siswa mampu menarik Siswa mampu menarik kesimpulan. (YB 116) kesimpulan. (YB 215)

Dari paparan wawancara di atas, terungkap bahwa subjek YB untuk indikator pemahaman konsep berdasarkan teori APOS (Mulyono, 2011) pada TPK I yaitu:

$P \quad: \quad$ Coba adik sebut hal-hal yang diketahui dari 107 soal tersebut

VD : Harga $7 \mathrm{~kg}$ terigu dan $2 \mathrm{~kg}$ gula sama 107 dengan $\mathrm{Rp}$. 70.000,- dan harga $3 \mathrm{~kg}$ terigu dan $2 \mathrm{~kg}$ gula sama dengan Rp. 38.000,-. Itu yang diketahui, pak

$P \quad: \quad$ Oke baik, kalau begitu apa ang ditanyakan?

108

VD : Yang ditanyakan harga $2 \mathrm{~kg}$ terigu dan $1 \mathrm{~kg}$ 108 gula pak

$P \quad: \quad$ Baik adik, kalau begitu coba adik jelaskan 109 yang adik tulis ini

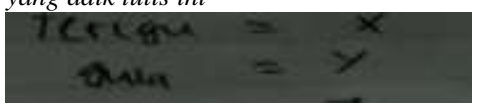

VD : Begini pak, pertama saya buat itu saya 109 misalkan terigu adalah $x$ dan gula adalah y barulah setelah itu saya ubah ke bentuk persamaan

$P \quad$ : Oke adik, kalau begitu coba adik jelaskan $114 \quad$ ini

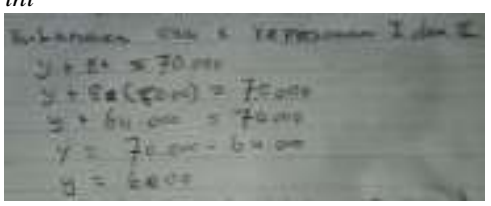

$V D \quad$ : Begini pak, setelah saya dapat nilai $x$ maka 114 saya substitusikan nilai $x$ ke persamaan satu dan persamaan dua untuk mendapatkan nilai $y$ 
$P \quad$ : Bagaimana adik yakin bahwa jawaban itu 120 benar?

$V D$ : Karena setelah saya kerjakan, saya dapat 120 nilai $x$ sama dengan Rp. 8.000,- dan y sama dengan $R$. 6.000,-

\section{Deskripsi Hasil TPK II}

Berikut hasil wawancara subyek VD pada TPK II:

P207 : Coba adik sebut hal-hal yang diketahui dari soal tersebut

VD : Harga $11 \mathrm{~kg}$ beras dan 5 buah apel sama 207 dengan $\mathrm{Rp}$. 123.000, - dan harga $6 \mathrm{~kg}$ beras dan 4 buah apel sama dengan Rp. 76.000,-. Itu yang diketahui, pak

P 208 : Oke baik, kalau begitu apa yang ditanyakan?

$V D \quad: \quad Y a n g$ ditanyakan harga $5 \mathrm{~kg}$ beras dan 2 buah

$208 \quad$ apel, pak

P209 : Baik adik, kalau begitu coba adik jelaskan yang ditulis ini

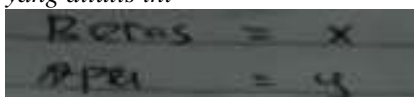

$V D \quad$ : Begini pak, pertama saya buat itu saya

209 misalkan beras adalah $x$ dan apel adalah $y$ baru setelah itu saya rubah ke bentuk persamaan

P 210 : Oke adik, terus langkah apa yang adik buat selanjutnya?

$V D \quad: \quad$ Saya gunakan metode eliminasi pak

210

P211 : Kalo begitu coba adik jelaskan ini

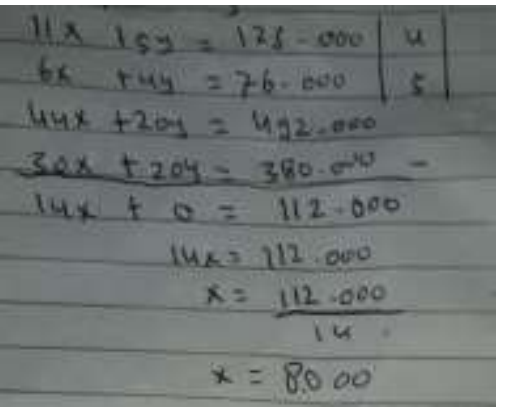

VD : Disini untuk mendapatkan nilai $x$ maka saya

$211 \quad$ eliminasi nilai y

P212 Oke adik, kenapa adik kalikan dengan 4 dan 5 ?

VD21 Supaya nilai y jadi sama pak

$P 213$

VD21

3

$P 214$

Ok adik, selanajutnya apa yang adik buat

Selanjutnya saya gunakan metode substitusi pak

Kalo begitu coba adik jelaskan ini

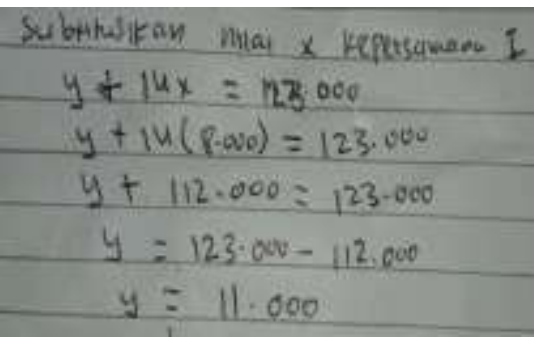

VD21 Begini pak, setelah saya dapat nilai $x$ maka $4 \quad$ saya substitusikan nilai $x$ ke persamaan satu dan persamaan dua untuk mendapatkan nilai y

P215 Kanapa harus substitusi ke persamaan satu dan dua?

VD21 Ya karena memang rumusnya begitu pak

P216 Apa adik yakin begitu?

VD21 Iya saya yakin pak

6

P217 Oke adik, coba adik jelaskan in

VD21

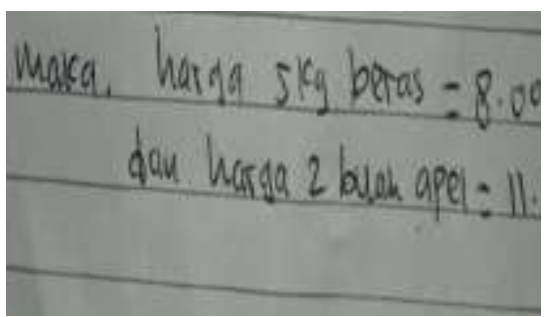

Disini saya buat kesimpulan harga $5 \mathrm{~kg}$ beras sama dengan Rp.8000 dan 2 buah apel sama dengan Rp 11.000

P218 Apa adik yakin?

VD21 Iya saya yain pak

8

P219 Kenapa adik bisa yakin?

VD21 Karena setelah saya kerjakan saya dapat nilai 9 $x$ sama dengan Rp 8.000 dan y sama dengan $R p$ 11.000

P220 Oke baik, terima kasih adik

VD22 Iya sama-sama pak

3. Validasi Data Subjek Berkemampuan Rendah

Untuk mengetahui validitas data kemampuan pemahaman konsep subjek VD berdasarkan teori APOS maka dilakukan triangulasi waktu untuk memperoleh kesamaan data wawancara. Triangulasi tersebut dalam dilihat pada Tabel 6.

Tabel 6. Validasi data Subyek VD

\begin{tabular}{|c|c|}
\hline TPK I & TPK II \\
\hline $\begin{array}{l}\text { Siswa mampu } \\
\text { menentukan apa yang } \\
\text { diketahui dalam soal. } \\
\text { (VD 107) }\end{array}$ & $\begin{array}{l}\text { Siswa } \\
\text { mampumenentukan } \\
\text { apa yang diketahui } \\
\text { dalam soal. (VD 207) }\end{array}$ \\
\hline $\begin{array}{l}\text { Siswa mampu } \\
\text { menentukan apa yang } \\
\text { ditanyakan dalam soal. } \\
\text { (VD 108) }\end{array}$ & $\begin{array}{l}\text { Siswa } \\
\text { mampumenentukan } \\
\text { apa yang ditanyakan } \\
\text { dalam soal. (VD 208) }\end{array}$ \\
\hline $\begin{array}{lr}\text { subyek } & \text { mampu } \\
\text { merubahsoal } & \text { kedalam } \\
\text { bentuk } & \text { kalimat } \\
\text { matematika. } & \text { (VD 109) }\end{array}$ & \begin{tabular}{lr}
\multicolumn{2}{l}{ Subyek } \\
mampumerubahsoal \\
kedalam & bentuk \\
kalimat & matematika. \\
(VD 209) &
\end{tabular} \\
\hline
\end{tabular}




\begin{tabular}{|c|c|}
\hline $\begin{array}{l}\text { Subyektidak mampu } \\
\text { menyelesaikan soal } \\
\text { dengan langkah- } \\
\text { langkah penyelesaian } \\
\text { secara tepat dan benar. } \\
\text { (VD 114) }\end{array}$ & $\begin{array}{l}\text { Subyektidak } \\
\text { mampumenyelesaikan } \\
\text { soal dengan langkah- } \\
\text { langkah penyelesaian } \\
\text { secara tepat dan benar. } \\
\text { (VD 215) }\end{array}$ \\
\hline $\begin{array}{l}\text { Subyek tidak mampu } \\
\text { menarik kesimpulan. } \\
\text { (VD 120) }\end{array}$ & $\begin{array}{l}\text { Subyek tidak } \\
\text { mampumenarik } \\
\text { kesimpulan. (VD 218) }\end{array}$ \\
\hline
\end{tabular}

Dari paparan wawancara di atas, terungkap bahwa subjek VD untuk indikator pemahaman konsep berdasarkan teori APOS (Mulyono, 2011) pada TPK Iyaitu:

1. Pada tahap tindakan

Subjek VD mampu menuliskan dan menjelaskan secara verbal apa yang diketahui dan ditanyakan dalam soal serta mampu menentukan dan menjelaskan secara verbal rencana untu menyelesaikan soal cerita yang berkaiatan dengan SPLDV

2. Pada tahap proses

Subjek VD mampu mengubah soal ke dalam bentuk matematika tanpa bantuan tulisan atau gambar serta mampu melakukan perhitungan langsung.

3. Pada tahap objek

Subjek VD tidak dapat menyelesaikan soal dan langkah yang digunakan masih salah serta alasan tidak sesuai dengan metode penyelesaian.

4. Pada tahap skema

Subjek VD tidak mampu mengunakan konsep serta salah prosedur dalam menyelesaikan soal cerita yang berkaitan dengan sistem persamaan linear dua vaiabel dan tidak tepat dalam menarik kesimpulan.

Dalam penelitian ini, dapat dilihat bahwa subyek berkemampuan tinggi dan berkemampuan sedang memenuhi keempat indikator teori APOS. Subyek berkemampuan rendah hanya memenuhi dua indikator. Indikator teori APOS yang dipenuhi oleh subyek berkemampuan rendah yaitu aksi dan proses. Sedangkan dua indikator lainnya yaitu objek dan skema tidak dipenuhi. Hal ini sejalan dengan yang dikatakan (Mulyono, 2011) bahwa siswa mengkonstruksi konsep matematika melalui empat tahap yaitu aksi, proses, objek dan skema. Pemenuhan keempat indikator ini ditelusuri melalui wawancara terhadap subyek.

\section{SIMPULAN}

Siswa berkemampuan tinggi dan sedang memenuhi indikator pemahaman konsep berdasarkan teori APOS, sedangkan siswa berkemampuan rendah tidak memenuhi indikator pemahaman konsep berdasarkan teori APOS. Dengan menerapkan pembelajaran yang tepat, diharapkan dapat meningkatkan pemahaman konsep siswa khususnya siswa dengan kemampuan rendah.

\section{DAFTAR PUSTAKA}

Daswa. (2013). Penerapan Model Sinektik untuk Meningkatkan Kemampuan Berpikir Kreatif dan Komunikasi Matematis Siswa Madrasah Tsanawijaya. Bandung: Repository UPI.

Depdiknas. (2003). Sistem Pendidikan Nasional. Jakarta: Depdiknas.

Lestari, S. W. (2014). Penerapan Model Pembelajaran M-APOS dalam meningkatkan Pemahaman Konsep dan Motivasi Belajar Kalkulus II. Jurnal pendidikan dan Keguruan, 1 - 13.

Mulyono. (2011). Teori APOS dan Implementasinya Dalam Pembelajaran. Journal of Mathematics and Mathematics Education, 37 - 45.

Sholikhakh, R. A., Rismono, \& Waluya, S. B. (2012). Pengembangan Perangkat Pembelajaran Beraacuan Konstruktivisme dalam Kemasan CD Interaktif Kelas VIII Materi Geometri dan Pengukuran. Unnes Journal of Research Mathematics Education, 13 19.

Sumliyah, \& Rhosliana, R. (2018). Peningkatan Kemampuan Pemahaman Konsep Matematis Melalui Desain Model Pembelajaran jaring laba-laba Berbasis Discovery Learning. Junal Hadharyah.

Turmudi. (2008). Landasan Filsafat dan Teori Pembelajaran Matematika. Jakarta: PT Leunseur Cita Nusa. 